\title{
Effect of Zoledronic Acid on Rats' Tissue SDF-1 Expression
}

\author{
Zafer ARIK ${ }^{1}$, Saadettin KILICKAP ${ }^{2}$, Ugur AKPULAT ${ }^{3}$, M. Ali NAHIT SENDUR ${ }^{4}$, \\ Y. Cetin KOCAEFE ${ }^{3}$, Mustafa ERMAN ${ }^{2}$ \\ ${ }^{1}$ Zekai Tahir Burak Women's Health Training and Research Hospital, Department of Medical Oncology \\ ${ }^{2}$ Hacettepe University, Institute of Cancer, Department of Medical Oncology \\ ${ }^{3}$ Hacettepe University Faculty of Medicine, Department of Medical Biology \\ ${ }^{4}$ Yildirim Beyazit University Department of Medical Oncology, Ankara, TURKEY
}

\begin{abstract}
Zoledronic acid has been shown to inhibit cancer cell proliferation, metastasis and induce cancer cell apoptosis. Stromal Derived Factor-1 (SDF-1) is a chemokine that has been reported to be expressed markedly high in the most common metastatic sites. The aim of this study was to investigate the effect of zoledronic acid on SDF-1 mRNA expression of rats' tissues. Rats were randomised into two groups, each containing five rats. Zoledronic acid was administered $0.1 \mathrm{mg} / \mathrm{kg}$ subcutaneously to one group. Other group was used as the control group. Seven days later, all rats were sacrificed. Levels of SDF-1 mRNA expression in tissues were measured quantitatively with RT-PCR. The median of SDF-1 mRNA relative expression in the lung was 0.80 (0.49-1.00) in the control group and 0.90 $(0.61-1.42)$ in the zoledronic acid group $(p=0.53)$. The median of SDF-1 mRNA relative expression in the liver was $0.90(0.39-1.00)$ in the control group and $0.93(0.77-1.29)$ in the zoledronic acid group $(p=0.35)$. In this study, we investigated the effect of zoledronic acid on the tissue SDF-1 mRNA expression for the first time in the literature. We observed that a single dose of zoledronic acid did not change SDF-1 expression in lung and liver of rats.
\end{abstract}

Keywords: Zoledronic acid, SDF-1, CXCR4, Lung, Liver

\section{ÖZET}

\section{Zoledronik Asidin Ratlarda Doku SDF-1 Ekspresyonu Üzerindeki Etkisi}

Zoledronik asidin kanser hücre proliferasyonunu ve invazyonunu inhibe ettiği ve kanser hücrelerinde apoptozise neden olduğu gösterilmiştir. Stromal derived factor-1 (SDF-1) meme kanserinin sık metastaz yaptığı dokularda yüksek düzeyde eksprese edilen bir kemokindir. Bu çalışmanın amacı zoledronik asidin, ratların doku SDF-1 mRNA ekspresyonu üstündeki etkisini saptamaktır. Beşerli iki gruba ayrılan ratların bir grubuna zoledronik asit $0.1 \mathrm{mg} / \mathrm{kg}$ s.c olarak verildi. Diğer grup kontrol grubu olarak kabul edildi. 7 gün sonra her iki grupdaki ratlar sakrifiye edildi. Alınan dokulardaki SDF-1 mRNA ekspresyonu kantitatif RT-PCR ile ölçüldü. Kontrol grubu ratlarda akciğerden ölçülen SDF-1 mRNA'ların relatif ekspresyonlarının ortancası 0.80 (0.49-1.00) iken zoledronik asit grubunda 0.90 (0.611.42) olarak saptandı ( $p=0.53$ ). Kontrol grubu ratlarda karaciğerden ölçülen SDF-1 mRNA'ların relatif ekspresyonlarının ortancası 0.90 (0.39-1.00) iken zoledronik asit grubunda $0.93(0.77-1.29)$ olarak saptandı $(p=0.35)$. Sonuç olarak, bu çalışma ile literatürde ilk kez zoledronik asidin doku SDF-1 m-RNA ekspresyonu üzerindeki etkisini inceledik. Tek doz zoledronik asidin ratlarda akciğer ve karaciğer SDF-1 ekspresyonunu değiştirmediğini saptadık.

Anahtar Kelimeler: Zoledronik asid, SDF-1, CXCR4, Akciğer, Karaciğer 


\section{INTRODUCTION}

Zoledronic acid is a new generation heterocyclic nitrogen containing bisphosphonate and is the most potent inhibitor of osteoclast-mediated bone resorption. It is used to treat osteoporosis, hypercalcemia of malignancy, as well as to prevent and to treat skeletal related events in cancer patients. ${ }^{1}$ Zoledronic acid inhibits cancer cell proliferation, metastasis, and induce cancer cell apoptosis in different cancer types in preclinical studies. ${ }^{2-6}$

Zoledronic acid has also been shown to reduce the risk of extra-skeletal metastasis and improve disease-free survival in early breast cancer patients. Addition of zoledronic acid to adjuvant therapy of early breast cancer patients represents a $36 \%$ reduction in the risk of disease progression. Patients who received zoledronic acid had significantly fewer events in bone metastasis, locoregional recurrence, and extra-skeletal metastasis also. ${ }^{7,8}$

Certain tumor types metastasize to specific organs. Stephen Paget, who lived in the 19th century, observed that breast cancer metastasize to the liver more than the spleen despite the same amount of blood flow to both organs. In 1889, Paget put forward that in the 'seed and soil' theory, cancer cells do not move randomly, and that each cancer cell (seed) metastasizes to its specific organ (soil). He proposed that microenvironment plays a critical role for homing of cancer cells. ${ }^{9}$

The accuracy of Paget's theory has been shown a century later. Greene et al show that interaction between tumor cells and luminal surface of the microvascular endothelium might be responsible for localization of metastasis. ${ }^{10}$ Stromal derived factor-1/CXCL-12 (SDF-1) is a chemokine which is secreted by those organs to which breast cancer metastases primarily and serves to home in breast cancer cells that has its receptor, CXCR4. Muller et al has shown that CXCR4 are highly expressed in human breast cancer cells. CXCR4's respective ligand SDF-1 is abundant in the first destinations of breast cancer metastasis such as lymph nodes, lung, liver, and bone marrow while very low in skin, small intestine. Neutralizing the interactions of SDF-1/CXCR4 significantly disrupt metastasis of breast cancer cells to regional lymph nodes and lung. ${ }^{11}$
We hypothesized that zoledronic acid shows antitumoral activity by reducing SDF-1 expression in target microenvironment (modulate the soil) and thus potentially influence tumor cell homing. To test this, levels of SDF-1 mRNA expression was determined after zoledronic acid injection in our preclinical study.

\section{MATERIAL AND METHODS}

\section{Animals}

A total of 10 adult female Sprague-Dawley rats, weighing 250-350 g were used in the study. They were housed in a temperature-controlled environment with a 12-h light-dark cycle. The rats were offered food and water ad libitum.

\section{Ethical Approval}

Study was conducted in accordance with the national guidelines for the use and care of laboratory animals and all procedures were approved by the Hacettepe Institutional Animal Care and Use Committee with by the ethical committee of the Faculty of Medicine of Hacettepe University.

\section{Experimental Protocol}

The rats were divided randomly into two groups, each containing 5 rats. Rats in the experimental group $(\mathrm{n}=5)$ administered single $0.1 \mathrm{mg} / \mathrm{kg}$ s.c zoledronic acid. The medication dosage used in this experiment were selected for being equivalent theoretically to the 4-mg intravenous dose given to patients. ${ }^{12}$ The control group $(n=5)$ was administered subcutaneously a single dose vehicle (normal saline). Seven day after the injection, rats were sacrificed by $\mathrm{CO}_{2}$ aspiration. The lungs, livers, and bone marrows were excised. RNA was extracted from the tissues. One $\mu \mathrm{g}$ of total RNA was reverse-transcribed with Promega RT system for synthesis of cDNA. Then cDNA was amplified by polymerase chain reaction (PCR) with specific primers as follows: SDF- $1 \alpha$ forward: $5^{\prime}-$ ACGGTAAGCCAGTCAGCCTGAG-3', reverse 5'TTCGGGTCAATGCACACTTGTCTG-3' (166 bp); $\beta$-actin forward: 5'-GTGCTATGTTGCC- 


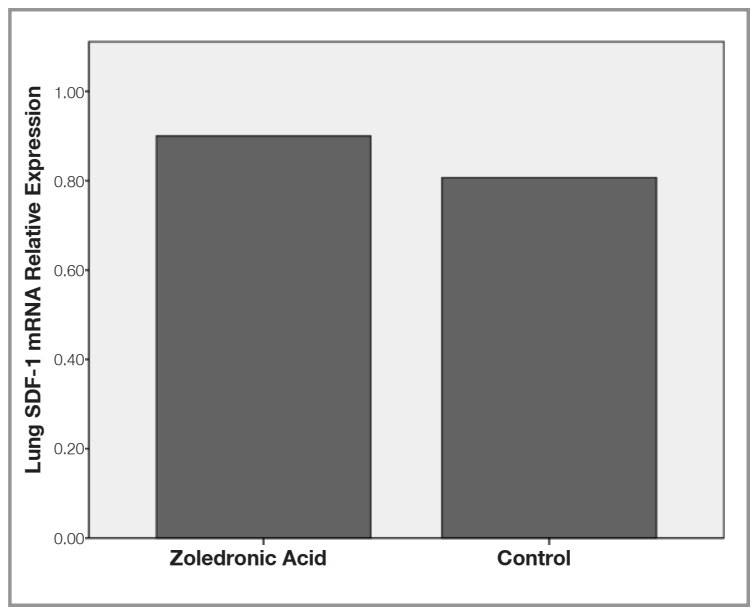

Figure 1. Lung SDF-1 mRNA relative expression

CTAGACTTCG-3', reverse: 5'-GATGCCACAGGATTCCATACCC-3(175 bp). $\beta$-actin was used as housekeeping gene for relative quantification of SDF-1 $\alpha$ mRNA expression. Reactions involved 2 min at $94^{\circ} \mathrm{C}, 45$ cycles at $94^{\circ} \mathrm{C}$ for one second, and $15 \mathrm{sec}$ at $61.5^{\circ} \mathrm{C}$. Levels of SDF-1 mRNA expression in tissues were analysed with RT-PCR (Rotor Gene 6000 PCR, Germany).

\section{Statistical Analysis}

Statistical analyses were performed by using SPSS for Windows version 18.0 (SPSS, Chicago, IL). Results were expressed as median. Statistical significance was determined by Student's T test. Values with a confidence level of $p \leq 0.05$ were considered significant.

\section{RESULTS}

\section{Lung SDF-1 mRNA Expression}

As shown in figure 1, median of SDF-1 mRNA relative expression in the lung was $0.80(0.49-1.00)$ in the control group and $0.90(0.61-1.42)$ in the zoledronic acid group $(\mathrm{p}=0.53)$.

\section{Liver SDF-1 mRNA Expression}

As shown in figure 2, median of SDF-1 mRNA relative expression in the liver was $0.90(0.39-1.00)$ in

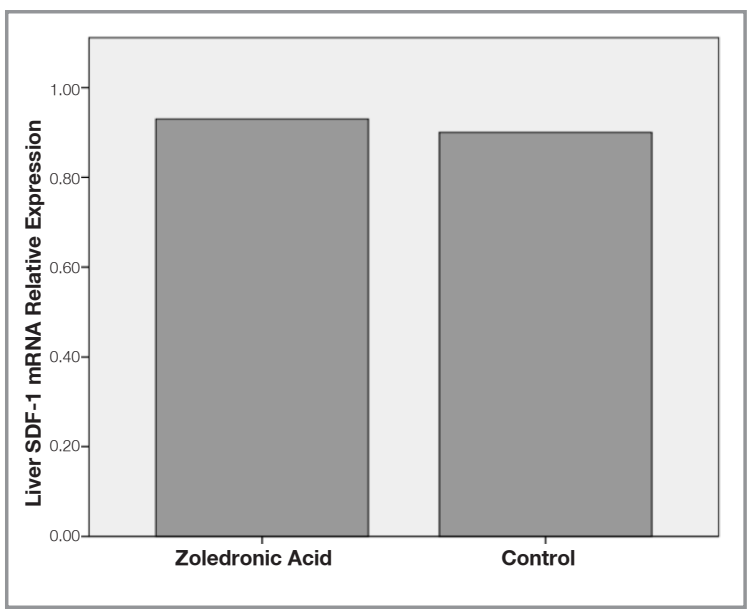

Figure 2. Liver SDF-1 mRNA relative expression

the control group and $0.93(0.77-1.29)$ in the zoledronic asid group $(\mathrm{p}=0.35)$.

\section{Bone Marrow SDF-1 mRNA Expression}

Because of technical disability we could not get measurable expression levels in the bone marrow samples.

\section{DISCUSSION}

In this study, we investigated the effect of zoledronic acid on the rats' tissue SDF-1 mRNA expression. In contrast to our expectations, we observed that a single dose of zoledronic acid did not result in reduced SDF-1 expression in lungs and livers of rats. Due to technical problems, we could not measure bone marrow SDF-1 mRNA expression in our study. Zoledronic acid has the major effect over bones. If we were able to measure SDF-1 in the bone marrows, we could possibly show the effect of zoledronic acid on bone microenvironment.

In our study, we used only one zoledronic acid injection. One injection may not be sufficient to prevent tumor progression. Haider et al. reported that a single dose of zoledronic acid rapidly induces significant alterations of bone microenvironment but does not reduce tumor cell numbers in bone. They suggest that while repeated biphosphonates cycles are not required for iniation of bone ef- 
fects, repeated dosing is required to prevent tumor growth in bone. ${ }^{13}$

ABCSG-12 and ZO-FAST trials show diseasefree survival benefit from adding zoledronic acid to adjuvant therapy of breast cancer. ${ }^{7,8}$ In contrast to these trials, in AZURE trial zoledronic acid did not show disease-free survival benefit in the overall patient population. Zoledronic acid was only effective in the disease-free survival of patients who were post-menopausal for at least 5 years before study entry. ${ }^{14}$ The anti-tumor effects of zoledronic acid might emerge only in post-menopausal status. This hypothesis was tested in a preclinical study. In this preclinical study, although zoledronic acid completely prevented tumor growth in bone in post-menopausal mice, it had no effect on the growth of tumor in pre-menopausal mice. ${ }^{15}$ They also found that zoledronic acid does not affect the lung metastasis (extra-skletal site) in either group. Not knowing the menopausal status of the rats used in our study may have affected the outcome of our study.

SDF-1/CXCR4 axis is one of the mechanism used by breast cancer cells for metastasis to bones. Chemotactic response induced by SDF-1 is mostly dependent on CXR4 receptor binding. Denoyelle et al. demonstrated that zoledronic acid inhibited the SDF-1 chemotactic effect of breast cancer cells by reducing CXR4 expression. ${ }^{16}$ Rather than the effect on SDF-1 expression in target tissues, reducing the CXCR 4 expression may be the anti-tumoral mechanism of zoledronic acid in SDF-1/CXCR4 axis.

In conclusion, we observed that a single dose of zoledronic acid did not result in reduced SDF-1 expression in lungs and livers of rats. The role of CXCR4 - SDF-1 axis in the anti-tumoral and antimetastatic activity of zoledronic acid needs to be evaluated in further studies.

\section{REFERENCES}

1. Buckler H, Fraser W, Hosking D, et al. Single infusion of zoledronate in Paget's disease of bone: a placebo-controlled, dose-ranging study. Bone 24(5 Suppl): 81S-85S, 1999.
2. Winter MC, Holen I, Coleman RE. Exploring the anti-tumour activity of bisphosphonates in early breast cancer. Cancer Treat Rev 34: 453-475, 2008.

3. Kiper HD, Tezcanli Kaymaz B, Gokbulut AA, et al. STAT pathway in the regulation of zoledronic acid-induced apoptosis in chronic myeloid leukemia cells. Biomed Pharmacother 67: 527-532, 2013.

4. S GR, Karabulut AB, Tuzcu M, et al. Combinatorial effect of zoledronic acid and irradiation on the prevention of DMBAinduced precancerogenic changes in the mammary tissues of rats. J Cancer Res Ther 12: 645-649, 2016.

5. Tassone P, Tagliaferri P, Viscomi C, et al. Zoledronic acid induces antiproliferative and apoptotic effects in human pancreatic cancer cells in vitro. Br J Cancer 88: 1971-1978, 2003.

6. Boissier S, Magnetto S, Frappart L, et al. Bisphosphonates inhibit prostate and breast carcinoma cell adhesion to unmineralized and mineralized bone extracellular matrices. Cancer research 57: 3890-3894, 1997.

7. Gnant M, Mlineritsch B, Stoeger $\mathrm{H}$, et al. Adjuvant endocrine therapy plus zoledronic acid in premenopausal women with early-stage breast cancer: 62-month follow-up from the ABCSG-12 randomised trial. Lancet Oncol 12: 631-641, 2011.

8. Coleman R, de Boer R, Eidtmann $\mathrm{H}$, et al. Zoledronic acid (zoledronate) for postmenopausal women with early breast cancer receiving adjuvant letrozole (ZO-FAST study): final 60-month results. Ann Oncol 24: 398-405, 2013.

9. Paget $\mathrm{S}$. The distribution of secondary growths in cancer of the breast. 1889. Cancer Metastasis Rev 8: 98-101, 1989.

10. Greene HS, Harvey EK. The Relationship between the Dissemination of Tumor Cells and the Distribution of Metastases. Cancer research 24: 799-811, 1964.

11. Muller A, Homey B, Soto $H$, et al. Involvement of chemokine receptors in breast cancer metastasis. Nature 2001, 410: 5056, 2001.

12. Daubine F, Le Gall C, Gasser J, et al. Antitumor effects of clinical dosing regimens of bisphosphonates in experimental breast cancer bone metastasis. J Natl Cancer Inst 99: 322330, 2007.

13. Haider MT, Holen I, Dear TN, et al. Modifying the osteoblastic niche with zoledronic acid in vivo-potential implications for breast cancer bone metastasis. Bone 66: 240-250, 2014.

14. Coleman R, Cameron D, Dodwell D, et al. Adjuvant zoledronic acid in patients with early breast cancer: final efficacy analysis of the AZURE (BIG 01/04) randomised open-label phase 3 trial. Lancet Oncol 15: 997-1006, 2014.

15. Ottewell PD, Wang N, Brown HK, et al. Zoledronic acid has differential antitumor activity in the pre- and postmenopausal bone microenvironment in vivo. Clin Cancer Res 20: 29222932, 2014. 
16. Denoyelle C, Hong L, Vannier JP, et al. New insights into the actions of bisphosphonate zoledronic acid in breast cancer cells by dual RhoA-dependent and -independent effects. Br J Cancer 88: 1631-1640, 2003.

\section{Correspondence:}

Dr. Zafer ARIK

Zekai Tahir Burak Kadın Sağlığı

Eğitim ve Araştırma Hastanesi

Tıbbi Onkoloji Bölümü

06100, Sihhiye, ANKARA / TURKEY

Tel: $\quad(+90-312) 3065634$

Fax: (+90-312) 3112485

E-mail: zaferarik@yahoo.com 